\title{
CULTURE-BOUND WEB-BASED INSTITUTIONAL ACADEMIC TEXTS. THE CASE OF SOME ROMANCE LANGUAGE UNIVERSITY WEBSITES IN ENGLISH
}

\author{
Ioana Carmen PĂȘTINARU* \\ Alexandru Ioan Cuza University of Iași, Romania
}

\begin{abstract}
The internationalisation process of European higher education over the past years largely encouraged the translation into English of many university websites. However, the (deliberate or nondeliberate) presence of culture-bound terms on the English version of university websites represents an issue of debate, considering the worldwide provenance of visitors accessing the websites and the purpose of these texts. The main goal of this article is to analyse the appropriateness of translation strategies used for the culturebound terms on university websites. The practical part of this research uses Aixelá's classification of translation strategies for the analysis of the culture-bound terms identified on some Romance language university webpages translated into English, allowing a series of suggestions and recommendations in each case. The study results have demonstrated that the strategy of conservation through repetition is used most often. Last but not least, this paper intends to raise awareness as to the translator's role and the impact of the quality of translations of university webpages into English as a lingua franca.
\end{abstract}

Keywords: culture-bound terms, university websites, web-based academic texts, translation strategies

\section{PRELIMINARY CONSIDERATIONS}

In the second decade of the $21^{\text {st }}$ century when the internet is fundamental for the future of all university missions, the translation of university websites, which currently represent one of the most powerful instruments bound to promote their institutional image overseas, have come to the attention of quite a number of translation scholars. Before approaching them as communication performances aiming to reach an intended audience, we should bear in mind that these web-

\footnotetext{
*ioanapastinaru@yahoo.com
} 
based institutional texts carry a heavy burden, that of being a reflection of universities themselves and of the quality of the education they provide.

The internationalisation process of the European Higher Education over the past years has expanded very much and the university strategies have included various undertakings which aim at making universities more visible and attractive to international students. These undertakings may refer to the provision of courses or academic programmes entirely taught in English, institutional involvement in academic exchange and mobility projects, the enlargement of cooperation with universities from all over the world, running international projects of research and innovation, etc. Nevertheless, none of these actions could be successful or sustainable without the web-based communication and the provision of institutional information in English as a lingua franca nowadays. The internationalisation process of higher education has thus triggered the translation of many European university webpages into English. Consequently, it is expected that the role of the translator as a professional enhance nolens volens due to the increased responsibility and the impact which the quality of the translations of websites has on universities in general.

In this context, the current study aims at examining and questioning the presence of the culture-bound terms on the English version of some Romance language university websites, analysing the strategies used for their translation and allowing a series of suggestions and recommendations in each case. Furthermore, the analytic dimension of the study is meant not only to reveal the current shortcomings in the translation of the cultural terms in the mentioned corpus, but also to set up a few basic guidelines and thus contribute to the general endeavours made by universities, which should streamline the clear and efficient communication of this type of texts.

\section{THE THEORETICAL BACKGROUND ON CULTURE-BOUND TERMS}

Translation scholars have widely explored the encounter of different cultures at the level of communication through languages, either spoken or written, hence their concern for the possibility and impossibility of translating culture. According to Hatim and Mason, "the notion 'culture-bound' may be defined in terms of the degree of 'universal currency' which the text in question enjoys." (Hatim \& Mason 1990:188). Snell-Hornby labels these terms as "realia or culture-bound elements" (Snell-Hornby 1995:106), agreeing that "the problems do not depend on the source text itself, but on the significance of the translated text for its readers as members of a certain culture". In the same line of thought, Hatim and Mason claim that "the degree of intervention by the translator will often depend on consumers and their needs" (Hatim \& Mason 1990:190). The functionalist approach, which defines translation as "a purposeful activity with 
the structure of the target text to be determined by the purpose it will have to fulfil in the target culture for the target audience” (Schäffner 2010:235), seems to be the most appropriate in our case since we are dealing with texts written for an audience and with a purpose.

For an accurate understanding of the intended meaning of the culturebound term it is important for the translator to first recognize it, be able to decode it and then place it in its proper context within the source culture. It is only afterwards that the translator continues with the identification of the most suitable translation strategy to be used. The choice of a certain translation strategy is also motivated by the nature of the culture-bound term. Aixelá (1996) (qtd. in Dimitriu 2002:74) suggests that the translator should consider a series of "explanatory variables" for which the translator may translate a cultural term one way rather than other. According to him, the nature of these parameters can be supratextual (degrees of linguistic prescriptivism, nature and expectations of potential readers, nature and aims of the initiators, working conditions, training and social status of the translators), textual (material textual constraints, the existence of previous translations, canonisation), or intratextual within the source text, relevance of the cultural term, coherence of the target text). In our case the "consumers" or target audience accessing the English websites are visitors from all over the world, making up an international audience of potentially huge cultural differences. Consequently, the target readers' educational background, their prior education, their linguistic competences, their previous contact with both the source and the target language, the intensity of their interactions with the source and target language people, their previous experiences with other cultures, the level of their intercultural competences, to name just a few, are all "supratextual variables" calling for the translator's concern. As for textual factors, it is expected that the translator of academic texts does his/her research regarding the strategy to be used for the translation of a culture-bound term that appears in a similar position on the websites of other universities. From Aixelá's taxonomy, the "textual variables" are possibly the most constraining in the case of the web-based academic texts and cannot be neglected. This may also be due to the digital genre which does not act only as text but also as medium, and the media is not only a distribution channel but also a carrier of meaning (Askehave \& Nielsen 2005: 1, 8). Finally, the intratextual feature of conveying coherent internet-based information by universities is not only a linguistic requirement of the "academic conversation" genre (Trosborg 1997:7), but also a recommendation of the European Council (in agreement with the Council Recommendation 2011/C 199/01 "Youth on the move").

Also referred to as "culture-specific items" (CSIs) (Aixelá 1996:59), “culturemes” (Katan 2009: 79), “culture specific references” (Chiaro 2009:156), "cultural specifics” (Ramière 2006:152), "extralinguistic culture-bound references” (Pedersen 2005:2), “cultural references” (Olk 2001:30), “culturally 
determined elements” (Hatim \& Mason 1990:198), these translation units identified in the web-based institutional texts represent a "problem for crosscultural transfer" (Ramière 2006:155). Even if Snell-Hornby's opinion that "little or no relationship exists at the level of realia or culture-bound elements" (Snell-Hornby 1995:106) is very categorical in this respect, the translation practice shows that the success of such translations depends on the degree of transculturality of the terms designating the cultural reference. Pedersen makes a very useful distinction between different methodologically relevant levels of transculturality, explaining that "the degree of transculturality of an extralinguistic culture-bound reference deals with how familiar it is to the source text and target text audiences" (Pedersen 2005:10). According to him, the culture-bound references can be transcultural (i.e. not bound to the source culture, but retrievable from the encyclopaedic knowledge of both the source and target text audiences), monocultural (bound to the source culture and less identifiable by the majority of the target text audience) and microcultural (bound to the source culture, but too specialized or local to be within the encyclopaedic knowledge of both source and target text audiences).

Aixelá groups the translation strategies that can be applied to culturespecific items (CSIs) into two categories, in relation to their nature: conservative and substitutive (Aixelá 1996:52). According to him, the strategy of conservation may be achieved through repetition, slight orthographic adaptations, linguistic (non-cultural) translation, extratextual or intratextual gloss. On the other hand, the strategy of substitution may be rendered through (partial) synonymy, limited or absolute universalisation, naturalisation, deletion, or autonomous creation. Starting from the premise that a text is translatable according to "the distance that separates the cultural background of the source text and target audience in terms of time and place" (Snell-Hornby 1988/1995:41), we will use Aixelá's classification of translation strategies for the analysis of the culture-bound terms identified on a series of Romance language university websites (Italian, French, Spanish and Portuguese) retrieved from electronic sources autumn 2017 - winter 2018. The identified culturespecific items will be analysed according to the category to which they belong, being divided into the following categories: holidays, food references, geographical names, local events, institutions / establishments, and educationspecific terminology.

\section{THE TRANSLATION STRATEGIES USED FOR CULTURE-BOUND TERMS ON ROMANCE LANGUAGE UNIVERSITY WEBSITES}

According to the distinction made by Pedersen (Pedersen 2005), Figure 1 below presents a case of monocultural term, bound to the source culture and less identifiable by the majority of the target audience. The course structure for 
bachelor's degrees provided by the University Rennes 2, introduces the religious holiday of All Saints' Day, a Christian festival celebrated in honour of all the saints, known and unknown. It is a public holiday in France which has always been celebrated on the $1^{\text {st }}$ of November. Rendered both through linguistic translation by one of its official equivalents - this celebration is also known as All Hallows' Day, Hallowmas, or Feast of All Saints (Britannica.com) - , and repetition (the translator decides to also keep the original French term, Toussaint, within brackets), the culture-bound term actually fails to communicate the exact period of the second alternative offered to students for choosing another degree course. The target readers would need further clarification as to the proposed calendar. Considering the diversity of religions followed by international students, as well as the text genre and medium, the strategy of explicitation, either through an intratextual or an extratextual gloss (the addition of the calendar day the $1^{\text {st }}$ of November), would have been preferable.
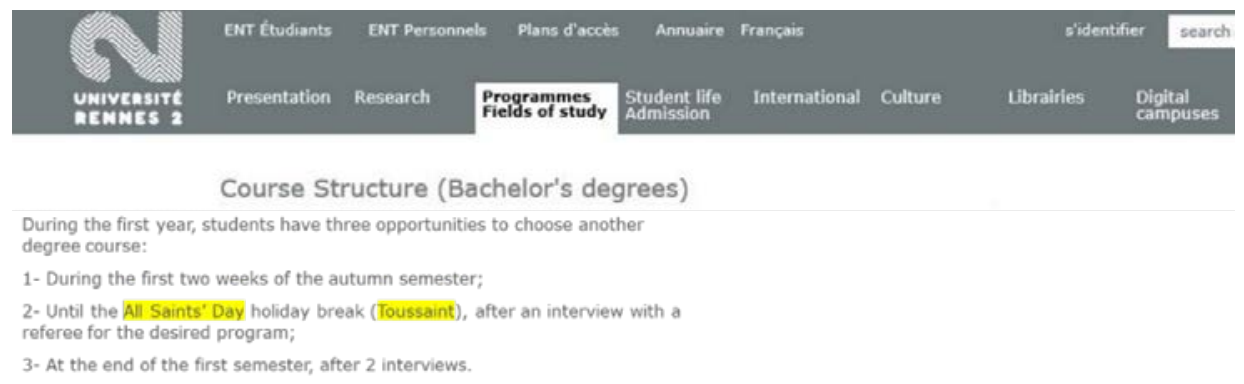

Figure 1 Screenshot from the website of Université Rennes 2 (Univ-rennes2.fr)

Figure 2 and Figure 3 below are placed side by side so we can compare the strategies used by two different universities for the same food reference, i.e. the transcultural term baguette. If the University of Lille simply transfers the reference, the University of Versailles uses two strategies at once, both repetition and an intratextual gloss. The expansion French bread stick is meant to disambiguate the culture-bound term, but it can be regarded as a patronizing act since the word has been included in the English dictionaries since the 1920s (Merriam-Webster.com) 


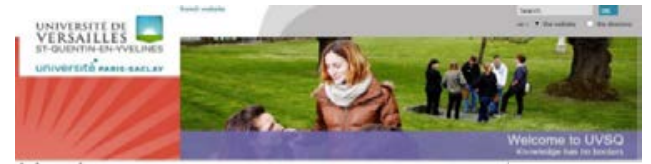

Meals

University dining

Food

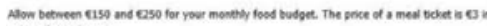

unvernity canteens.

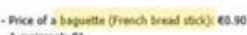

A coissume 6

A A ther of mate 60.90

A pacter of coffees 6

tha d ace: 6130

-9000 d ponte: $e$ :

12 epse e. 1.50

2509 of tween 61.20

A rot drink 6.90

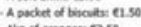

- 1ho of armges: 2.50

Alumplochio

A fot tood menow 66.50

A medil in a restaurant betions

Figure 2 Screenshot from the website of

Université de Versailles Saint-Quentin-enYvelines (Uvsq.fr)

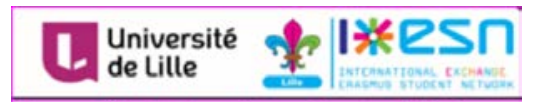

Le coût de la vie - Cost of living pour te donner une idee du cout de To give you an idea of the cost of la vie dans la métropole ilioise, voic life in the metropolis, here are a few vielques exempirante.

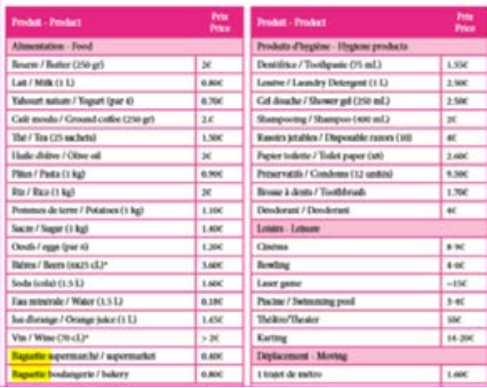

Figure 3. Screenshot from the website of Université de Lille (Esnlille.fr)

The following examples are also transcultural terms, retrievable from the encyclopaedic knowledge of both the source text and the target text audiences. The website of the Paris Nanterre University (see Figure 4 below) informs that the campus cafeteria sells paninis, ciabattas and bagels. The confusion arises when the term paninis is used in the enumeration following the term sandwiches, implying the two designate different things, whereas panini is a sandwich. The strategy of repetition is also used for ciabattas and bagels, monocultural terms which have turned into transcultural ones with the age of internationalization.

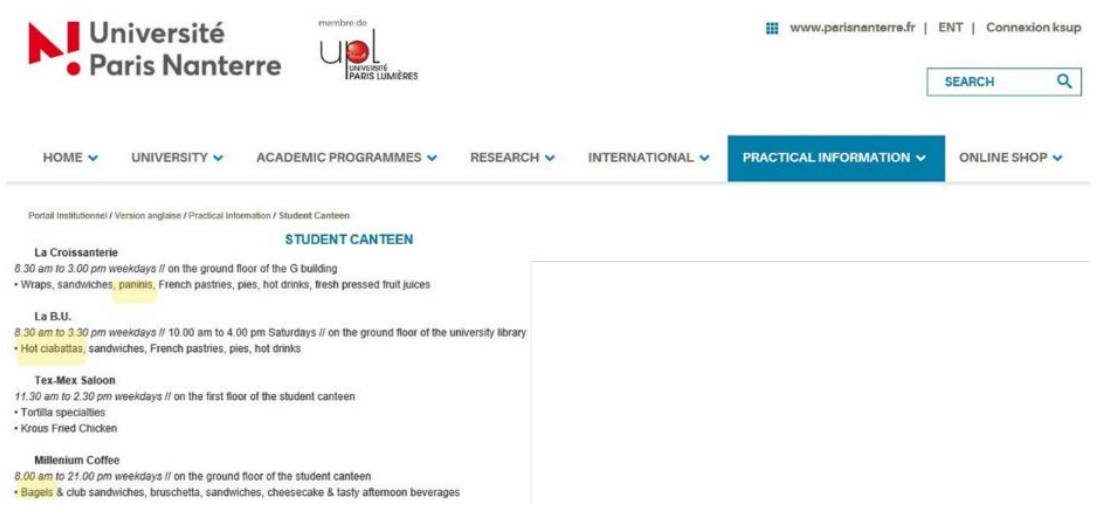

Figure 4 Screenshot from the website of Université Paris Nanterre (University.parisnanterre.fr) 
On the other hand, the strategy of repetition used for the monocultural term quiches (see Figure 5 below) leaves the reference less overt, and provides international students with no concrete information about the ingredients. Figure 6 below is a perfect illustration of microcultural terms, bound to the source culture only and too local to be within the encyclopaedic knowledge of both the source text and target text audiences. In their intention to promote the university region, the University of Lille preserves the French original cultural terms designating the traditional food in the North of France, such as le maroilles, les merveilleux, le potjevleesch, le welsh, or les moules-frites. The strategy of repetition is preferred in their case not solely for the sake of foreignization, introducing the target readers into the local cultural atmosphere, but also because they represent what Leppihalme calls "culture bumps" (Leppihalme 1997). The non-verbal elements (the carefully selected photographs which give a hint of the subject matter) are equally multicultural, thus enhancing the text's effect.

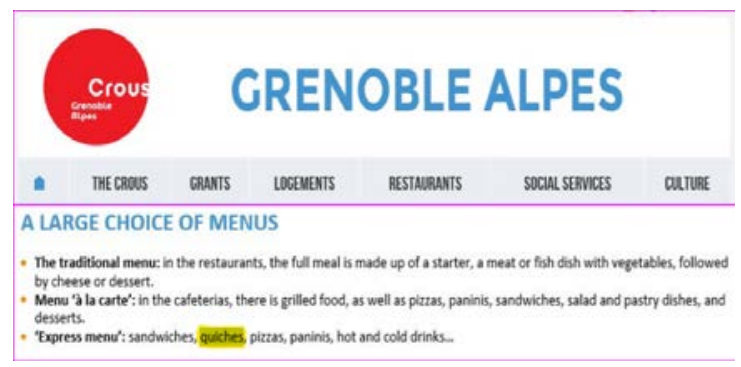

Figure 5. Screenshot from the CROUS website of Université Grenoble Alpes (Crous-grenoble.fr)

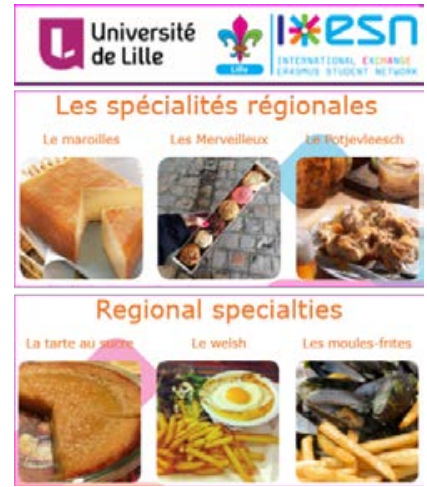

Figure 6 Screenshot from the website of Université de Lille (Esnlille.fr)

In the same category of food, the Portuguese culture-bound terms Bife à Café and Pastel de Nata are treated differently in translation. While the cultural term Bife à Café is rendered only through repetition, borrowed as such on the English version of the University of Lisbon website, the translation of the term Pastel de Nata is achieved both through repetition and absolute universalisation. The neutral reference custard tart, placed between brackets, is thought to delete any foreign connotation of the term, it being part of the culinary world knowledge of the target text readers. The different translation approaches and strategies applied to apparently similar translation units can be explained by their different levels of transculturality (Pederson 2005). If Pastel de Nata is a monocultural term (originally from Portugal, but which can also be found in countries with significant Portuguese immigrant populations), the term Bife à 
Café is microcultural, too local to transcend the borders of the Portuguese cuisine and therefore left without any equivalent in the target text

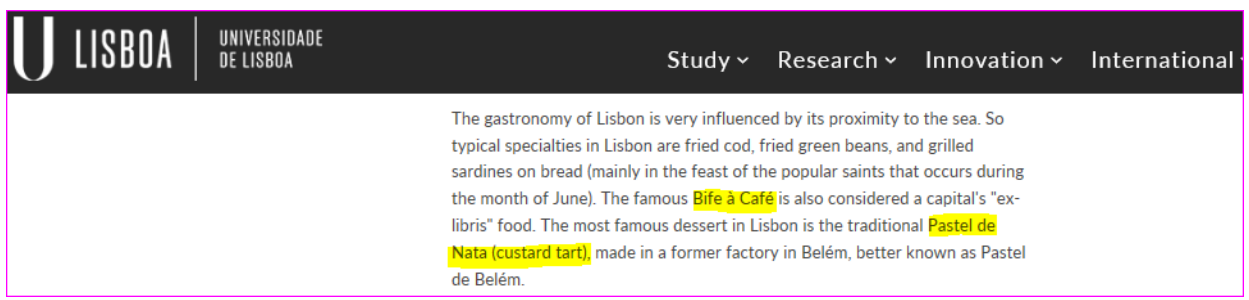

Figure 7 Screenshot from the website of Universidade de Lisboa (Ulisboa.pt)

Another case of monocultural term is the geographical name Asturias (see Figure 7 below) used in the column title Asturias' University. If the culturebound term were left unexplicitated, the target audience would have to turn to other sources to establish whether the proper name Asturias refers to a place or a person. Therefore, the explicitation the Principality of Asturias used in the first paragraph clarifies the cultural reference.

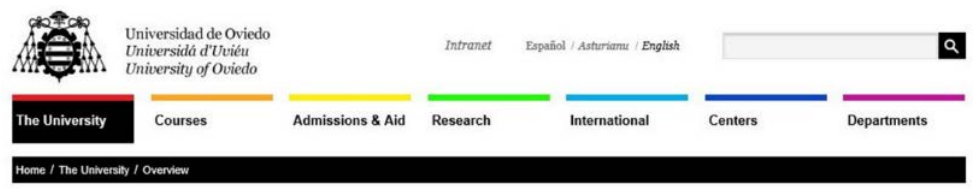

Asturias' University

The University of Oviedo is a public institution of higher education and research in the Principality of Asturias. With over 400 years of history, it offers a full range of undergraduate degrees adapted to the European Higher Education Area (EHEA) in all branches of knowledge and postgraduate degree programmes in collaboration with national and international universities and more than 250 companies.

Figure 8 Screenshot from the website of Universidad de Oviedo (Uniovi.es)

We can further exemplify the strategy of conservation through repetition with the names of some French events (see Figure 8 below), i.e. the transcultural Journées d'Immersion dans la Vie Étudiante and the microcultural braderie de Lille, which are borrowed from the French source text into the English target text without any gloss or explicitation. A widely used term for the events intended to guide international students through the campus and introduce them to the academic and social opportunities of a university is welcome days, which could have gotten the message through the target audience. The braderie de Lille, on the other hand, was translated by the Independent (Independent.co.uk) as Lille flea market, which means that the translator did not 
search for the existence of previous translations of the same term, as a textual variable (Aixelá 1996). Not to mention the microcultural term la Brocante de Maroilles, which was poorly translated using the strategy of limited universalisation, as the goodwill shop of Maroilles and which, in fact, is an antique fair or a vintage market.

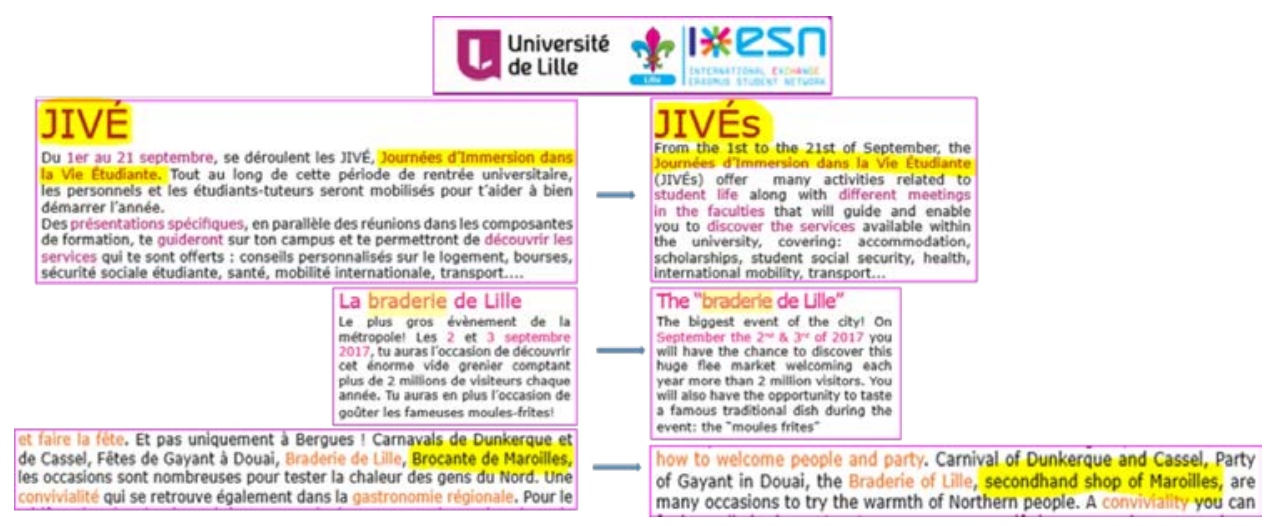

Figure 9 Screenshots from the website of Université de Lille (Esnlille.fr)

The names of local institutions or establishments are most of the times rendered in translation through repetition. The same monocultural term appears in both Figure 9 and Figure 10 below, namely the place name Café Langues. The University of Paris Nanterre resorts to two strategies for the translation of this cultural term: since its repetition is not seen as explicit enough, the strategy of absolute universalization is additionally used within brackets (Language Resource Center), acting as an extreme strategy and destroying the cultural function of the term. Its simple repetition in the text translated by the University of Lille simply increases the exotic character of the cultural item in question, keeping the social features of the place, beside its educational purposes. However, British universities currently use the term Languages Café (see, for example, Plymouth.ac.uk) which signifies that neither of the above-mentioned universities checked the existence of this cultural reference on native English university websites. 


\section{L'aide au logement}

En France, tu as la possibilité d'obtenir une aide au logement auprès d'un organisme guil s'oppelle la CAF (Caisse drallocations Fomiliales). L'aide dépend du montant de ton loyer et pourra t'étre attribuée tous les mois.

\section{Housing benefit}

In France, you may have a housing benefit to help you with your rent. According to the price of your rent, you can receive some money.

Figure 13 Screenshot from the website of Université de Lille (Esnlille.fr)

For the translation of the transcultural terms écoles primaires, colleges et lycées belonging to the same category of institutions (see Figure 14 below), the University of Lille used the strategy of partial synonymy most probably in order to generalize the given situation so that the focus of the text message may be on other elements. The term écoles primaires becomes schools, the elementary element as a differentiated type of school being ignored, while the terms colleges et lycées are merged into a single general term, highschools, which again lacks the specificity of each of the two types of French education institutions.

ErasmUS in SchoOls
Erasmus in Schools te met en contact avec Erasmus in Schools connects you
les élèves des écoles primaires, collèges with local schools and highschools
et lycées de la région dans le but de créer in order to create intercultural
des échanges interculturels. Présente ton exchanges. Introduce your own
propre pays et ta culture, témoigne de ton country and its culture, relate your
expérience à l'étranger, débats sur des own international experience, debate
sujets d'actualité internationale, anime about international hot topics,
des ateliers de langue... Une opportunité conduct language workshops, ... A
de s'intégrer un peu plus au niveau local great opportunity to integrate and
et de vivre une expérience enrichissante! live a rewarding experience!

Figure 14 Screenshot from the website of Université de Lille (Esnlille.fr)

As for the culture-bound terms denoting education-specific terminology, the most commonly used strategy is conservation, which is achieved either through repetition, or linguistic (non-cultural) translation, the translator's choices being conditioned and motivated by the profile of the target text audience and the purpose of the translation, which is consistent with the functionalist approach. It often happens that both the repetition and the linguistic translation of the culturally determined element are used at the same time, probably in an effort to convey the information in the target text in the clearest way possible. Items like specialista (see Figure 15 below), ad accesso programmato, con prova di accertamento obbligatoria, and con requisiti di ammissione (see Figure 16 below), frequentanti and non-frequentanti (see Figure 17 and Figure 18 below), licence and unités d'enseignement (see Figure 19 below) are both borrowed from the source text to the target text, as well as linguistically translated - usually within brackets (see specialist, restricted number of places, compulsory assessment test, admission requirements, 
attending, not attending, bachelor's degree, and credits respectively), which makes it maintain the original reference and increase its understandability.

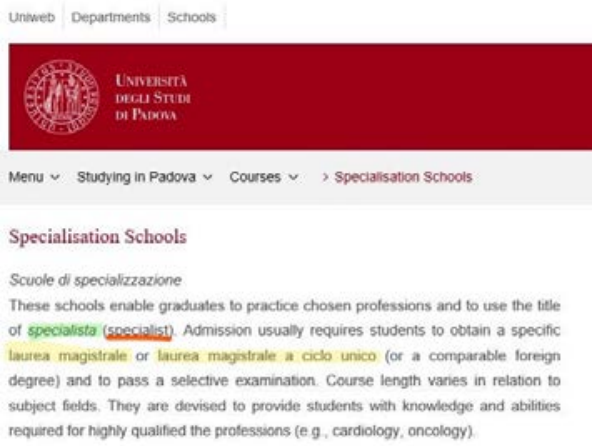

Figure 15 Screenshot from the website of Università degli Studi di Padova (Unipd.it)

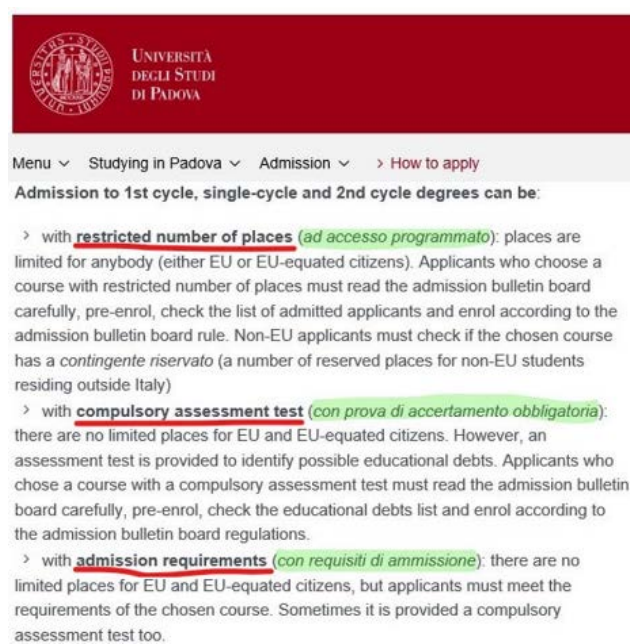

Figure 16 Screenshot from the website of Università degli Studi di Padova (Unipd.it)

Deciding on the strategy of repetition for the translation of other culturebound terms specific to the field of education raises doubts, as in the case of the pairs Laurea magistrale and Laurea magistrale a ciclo unico (see Figure 15 above), or Travaux Dirigés and Travaux Pratiques (see Figure 19 below, left), as well as the tripartite Diplôme universitaire de technologies, Diplômes universitaires, and Diplômes inter-universitaires (see Figure 19 below, right). The distinction between the respective items is crucial to the text and would have to be made explicit through a gloss, either extratextual (a glossary on the university webpage, for example) or intratextual so as to require minimum effort from the target audience. In an expository text on the Italian/French education system, the borrowing of the source text elements into the target text might be appropriate, but not here, all the more so since the distinction between the cultural items cannot be inferred "whether from co-text or because it is situationally relevant" (Hatim \& Mason 1990: 93). Relating to the issue of inference from the point of view of translation studies, Hatim and Mason claim that "what is inferable or situationally evoked for a source text reader may not be so for a target text reader. Operating in different cognitive environments, source text and target text readers are not equally equipped for the task of inferencing." (Ibidem). 


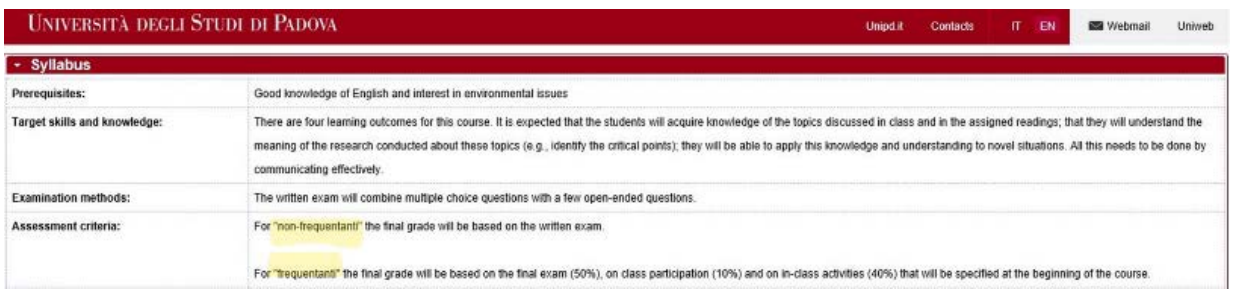

Figure 17 Screenshot from the website of Università degli Studi di Padova (Unipd.it)

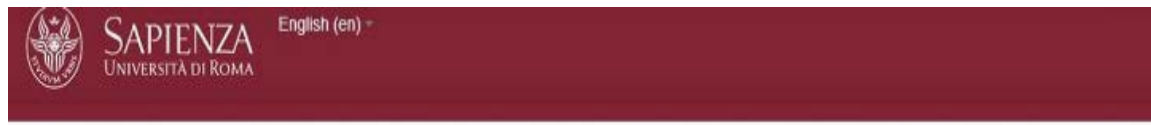

Home > Courses > Facoltà > Lettere e Filosofia > PSHJK_2016 > Summary

Political and Social History of Modern and Contemporary Japan and Korea A, 2016-2017

Teacher. Marco Del Bene

II corso prevede due percorsi, per frequentanti e per I non frequentanti.

The course is for both students attending or not attending the lessons.

Figure 18 Screenshot from the website of Università di Roma Sapiena (Uniroma1.it)

Université de Rennes 1

International school

\section{LMD}

Licence, master and doctorate are the three levels in the French Higher Education system otherwise known as LMD. A similar structure can be found throughout the European Union, facilitating student mobility in Europe and around the world.

Licence

The licence (bachelor's degree) lasts for three years and consists of basic multidisciplinary training leading to a degree, which then allows students to go on to study for a master's degree.

A licence is made up of 6 semesters. Each semester is divided into credits known as unités d'enseignement or UE's. When UE's have been validated, students gain ECTS (European Credit Transfer System) credits. One semester is equal to 30 credits. These credits are taken into account when moving from one European institution to another.

Teaching in French universities takes the form of lectures (large groups of students in lecture theatres) and practical courses in smaller groups known as Travaux Dirigés or TD and Travaux Pratiques or TP.

\section{Université de Rennes 1}

international school

\section{A wide choice of training options}

As well as the LMD curriculum, Université de Rennes 1 also prepares national diplomas such as the DUT (Dip/ôme universitaire de technologies) and, amongst others, diplomas in healthcare and engineering. It has also created its own specific diplomas: DU (Diplômes universitaires) and DIU (Dip/ômes inter-universitaires).

Figure 19 Screenshots from the website of Université de Rennes 1 (Univ-rennes1.fr)

It often happens that two translators choose different strategies for the translation of the same cultural term. However, it should be pointed out that the inconsistency in applying different strategies for the translation of the same culture-bound term (by the same translator) is not always deliberate and may betray the translator's lack of experience. In Figure 19 below the term validation 
d'études acts as a constitutive part of the phrase to make a "validation d'études". On closer investigation, only two paragraphs farther on the same page, the term is rendered through linguistic translation as validation of studies, which means that the sentence you have to make a "validation d'études" could have been translated as you have to validate your studies.

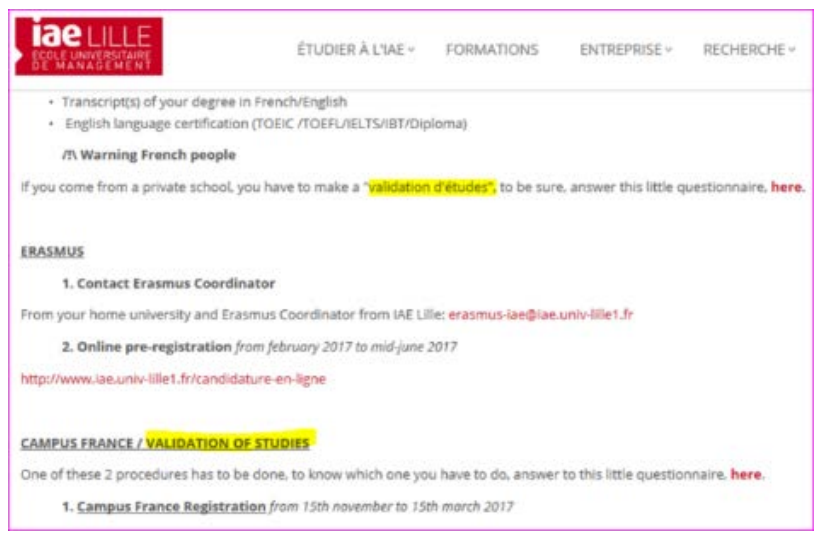

Figure 20 Screenshot from the website of Université de Lille 1(Univ-lille1.fr)

An example of naturalization (the cultural term is radically replaced by the target culture correspondent) appears in Figure 21 below where the French mention assez bien en L3 (12/20 à l'année de L3, minimum) is translated by the specialized term upper second class honor minimum, or first class honor, which belong to the British undergraduate degree classification system. When dealing with such specialized terminology, the introduction of an extratextual gloss (a glossary on the university website) would be highly recommended. The consequences of not conveying clear information about this cultural term, whose meaning still remains obscure for the international students whose origins are not British or who have not studied in the British education system before, could be quite serious if the prerequisites for enrolling in the respective master programme were not met.

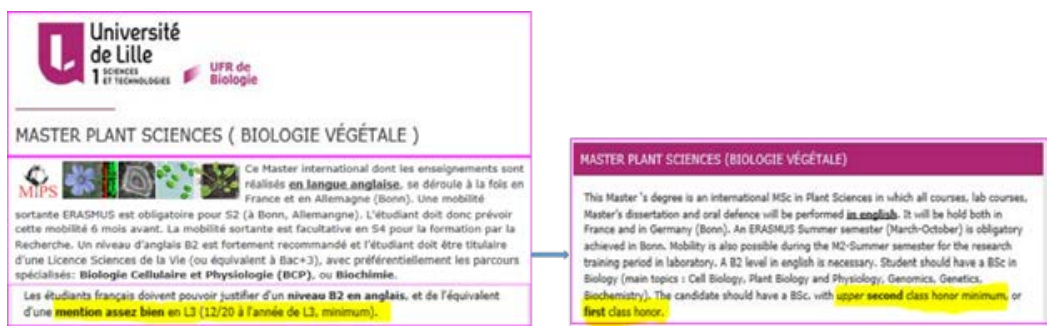

Figure 21 Screenshot from the website of Université de Lille 1 (Univ-lille1.fr) 
Table 1 below summarizes the translation strategies used for the culturebound terms identified in the analysed corpus of university websites. The first column indicates the category to which the terms belong, the second and third columns include the source text and target text culture-bound terms. Column four specifies the strategy(ies) used for the translation of the original cultural term into English, while column five shows whether or not there are alternative solutions that the translator could have provided instead of the ones used in column three.

Table 1 Translation strategies used for culture-bound terms

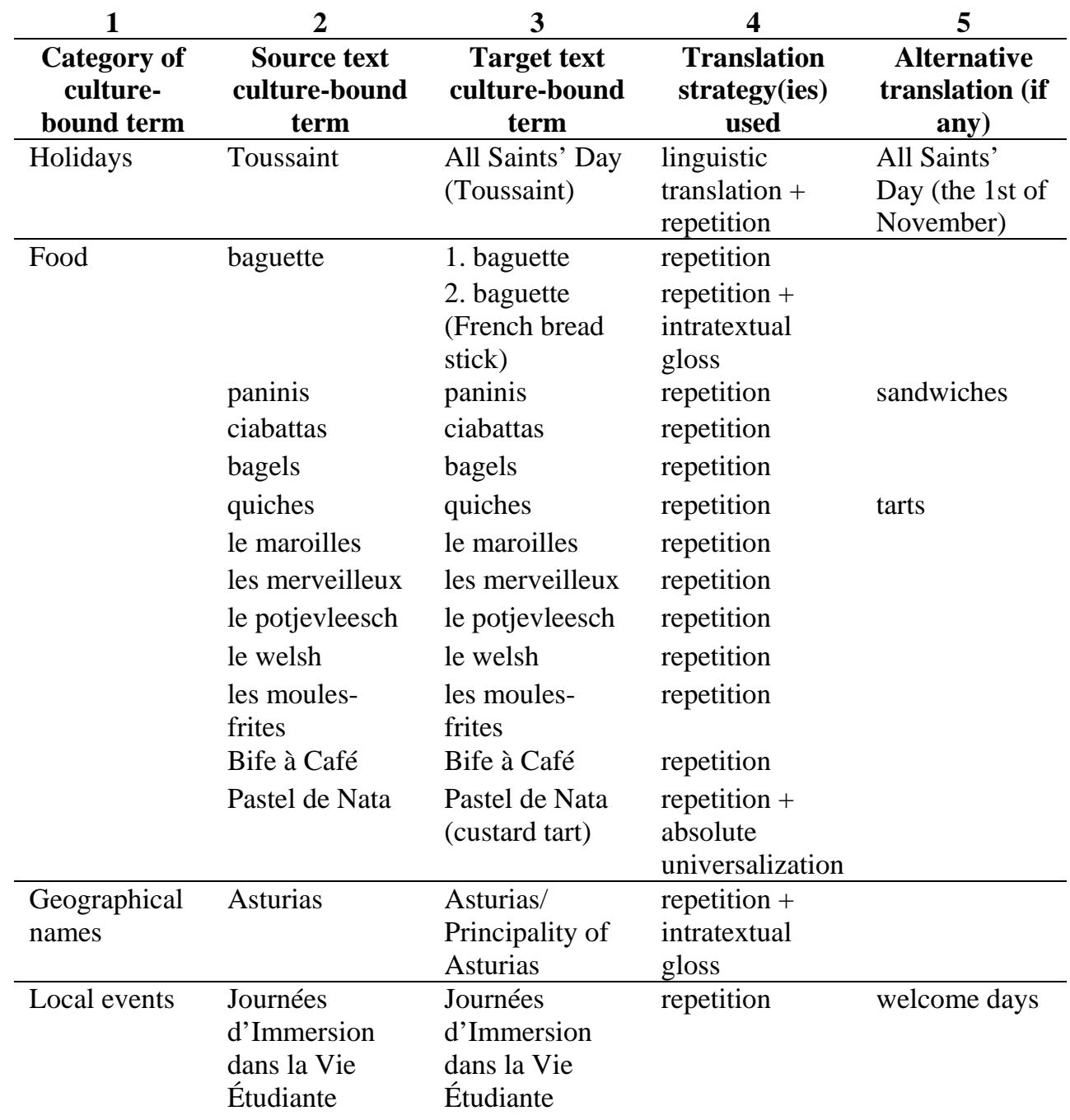




\begin{tabular}{|c|c|c|c|c|}
\hline & $\begin{array}{l}\text { braderie de } \\
\text { Lille } \\
\text { Brocante de } \\
\text { Maroilles }\end{array}$ & $\begin{array}{l}\text { braderie de } \\
\text { Lille } \\
\text { secondhand } \\
\text { shop of } \\
\text { Maroilles }\end{array}$ & $\begin{array}{l}\text { repetition } \\
\text { limited } \\
\text { universalization }\end{array}$ & $\begin{array}{l}\text { Lille flea } \\
\text { market } \\
\text { Maroilles } \\
\text { antique fair / } \\
\text { Maroilles } \\
\text { vintage market }\end{array}$ \\
\hline \multirow{6}{*}{$\begin{array}{l}\text { Institutions / } \\
\text { establishment } \\
\mathrm{s}\end{array}$} & \multirow[t]{2}{*}{ Café Langues } & $\begin{array}{l}\text { 1. Café } \\
\text { Langues }\end{array}$ & repetition & $\begin{array}{l}\text { Languages } \\
\text { Café }\end{array}$ \\
\hline & & $\begin{array}{l}\text { 2. Café } \\
\text { Langues } \\
\text { (Language } \\
\text { Resource } \\
\text { Center) }\end{array}$ & $\begin{array}{l}\text { repetition }+ \\
\text { absolute } \\
\text { universalization }\end{array}$ & $\begin{array}{l}\text { Languages } \\
\text { Café }\end{array}$ \\
\hline & $\begin{array}{l}\text { Serviços de } \\
\text { Estrangeiros e } \\
\text { Fronteiras }\end{array}$ & $\begin{array}{l}\text { Foreign Office } \\
\text { (SEF-Serviços } \\
\text { de Estrangeiros } \\
\text { e Fronteiras) }\end{array}$ & $\begin{array}{l}\text { repetition }+ \\
\text { absolute } \\
\text { universalization }\end{array}$ & \\
\hline & $\begin{array}{l}\text { CAF (Caisse } \\
\text { d'Allocations } \\
\text { Familiales) }\end{array}$ & & omission & $\begin{array}{l}\text { Family } \\
\text { Allocations } \\
\text { Office }\end{array}$ \\
\hline & $\begin{array}{l}\text { écoles } \\
\text { primaires }\end{array}$ & schools & $\begin{array}{l}\text { partial } \\
\text { synonymy } \\
\text { (generalization) }\end{array}$ & $\begin{array}{l}\text { elementary } \\
\text { schools }\end{array}$ \\
\hline & $\begin{array}{l}\text { collèges and } \\
\text { lycées }\end{array}$ & highschools & $\begin{array}{l}\text { partial } \\
\text { synonymy } \\
\text { (generalization) }\end{array}$ & $\begin{array}{l}\text { colleges and } \\
\text { high schools }\end{array}$ \\
\hline \multirow[t]{3}{*}{$\begin{array}{l}\text { Education- } \\
\text { specific } \\
\text { terminology }\end{array}$} & specialista & $\begin{array}{l}\text { speciatista } \\
\text { (specialist) }\end{array}$ & $\begin{array}{l}\text { repetition }+ \\
\text { linguistic } \\
\text { translation }\end{array}$ & \\
\hline & $\begin{array}{l}\text { ad accesso } \\
\text { programmato }\end{array}$ & $\begin{array}{l}\text { restricted } \\
\text { number of } \\
\text { places (ad } \\
\text { accesso } \\
\text { programmato) }\end{array}$ & $\begin{array}{l}\text { linguistic } \\
\text { translation + } \\
\text { repetition }\end{array}$ & \\
\hline & $\begin{array}{l}\text { con prova di } \\
\text { accertamento } \\
\text { obbligatoria }\end{array}$ & $\begin{array}{l}\text { compulsory } \\
\text { assessment test } \\
\text { (con prova di } \\
\text { accertamento } \\
\text { obbligatoria) }\end{array}$ & $\begin{array}{l}\text { linguistic } \\
\text { translation + } \\
\text { repetition }\end{array}$ & \\
\hline
\end{tabular}




\begin{tabular}{|c|c|c|c|}
\hline $\begin{array}{l}\text { con requisiti di } \\
\text { ammissione }\end{array}$ & $\begin{array}{l}\text { admission } \\
\text { requirements } \\
\text { (con requisiti di } \\
\text { ammissione) }\end{array}$ & $\begin{array}{l}\text { linguistic } \\
\text { translation + } \\
\text { repetition }\end{array}$ & \\
\hline \multirow[t]{2}{*}{$\begin{array}{l}\text { frequentanti/ } \\
\text { non- } \\
\text { frequentanti }\end{array}$} & $\begin{array}{l}\text { 1. frequentanti/ } \\
\text { non- } \\
\text { frequentanti }\end{array}$ & repetition & $\begin{array}{l}\text { students } \\
\text { attending/ } \\
\text { students not } \\
\text { attending }\end{array}$ \\
\hline & $\begin{array}{l}\text { 2. students } \\
\text { attending/ } \\
\text { students not } \\
\text { attending }\end{array}$ & $\begin{array}{l}\text { linguistic } \\
\text { translation }\end{array}$ & \\
\hline \multirow[t]{2}{*}{ licence } & 1. licence & repetition & \\
\hline & $\begin{array}{l}\text { 2. licence } \\
\text { (bachelor's } \\
\text { degree) }\end{array}$ & $\begin{array}{l}\text { repetition + } \\
\text { linguistic } \\
\text { translation }\end{array}$ & bachelor \\
\hline $\begin{array}{l}\text { unités } \\
\text { d'enseignement }\end{array}$ & $\begin{array}{l}\text { unités } \\
\text { d'enseignement }\end{array}$ & repetition & credits \\
\hline \multirow[t]{2}{*}{$\begin{array}{l}\text { validation } \\
\text { d'études }\end{array}$} & $\begin{array}{l}\text { 1. validation } \\
\text { d'études }\end{array}$ & repetition & $\begin{array}{l}\text { validation of } \\
\text { studies }\end{array}$ \\
\hline & $\begin{array}{l}\text { 2. validation of } \\
\text { studies }\end{array}$ & $\begin{array}{l}\text { linguistic } \\
\text { translation }\end{array}$ & \\
\hline $\begin{array}{l}\text { mention assez } \\
\text { bien en L3 } \\
\text { (12/20 à l'année } \\
\text { de L3, } \\
\text { minimum) }\end{array}$ & $\begin{array}{l}\text { upper second } \\
\text { class honor } \\
\text { minimum, or } \\
\text { first class honor }\end{array}$ & naturalisation & $\begin{array}{l}\text { upper second- } \\
\text { class honours } \\
\text { minimum }\end{array}$ \\
\hline
\end{tabular}

The corpus of university websites includes thirty-one culture-bound terms, five of which were recognised on two different websites, therefore two alternatives for their translation are provided for them in the third column of Table 1 above. The most often used translation strategy for the analysed culturebound terms is repetition, identified in thirty instances. Linguistic translation was used in nine instances, absolute universalization in four, partial synonymy in three, while strategies like naturalisation, limited universalization and omission were used only in one instance each.

The overwhelming use of repetition (or cultural borrowing), followed by the linguistic (non-cultural) translation of the cultural terms, leads us to the conclusion that the preferred translation strategy is conservation, which suggests not only linguistic nationalism on the part of the Romance language universities whose websites have been analysed, but also the concern to preserve their unique national culture within the European diversity of cultures. Nevertheless, in spite of the linguistic and cultural conservation aimed at promoting the 
national language, values and traditions, the English version of the university websites calls most importantly for clarity of information, which is primordial in our case. For that reason, as it has been suggested through the alternatives provided for the translation of some culture-bound terms, other translation strategies should be used to a larger extent to make the content culturally acceptable to international students. Aside from the idea of conservation and promotion of one's own language and culture, there is also a natural tendency to assimilate the culture-bound term, as an easier option. Yet, translators need to negotiate the appropriate balance, so that translations remain accessible to a wide readership. Otherwise, translated texts would fail to be a force for crosscultural understanding. The diversification of strategies would aim to supplement the readers' cultural knowledge (see the use of glossaries) and universalize the terms when their cultural meaning is too obscure, in line with the correct and consistent norms regarding the elaboration of web-based institutional academic texts.

\section{RECOMMENDATIONS AND CONCLUSIONS}

The following minimum recommendations regarding the translation of cultural terms on university websites, based on the empirical research of this study, will be advanced:

To use correct and consistent terminology (e.g. validation d'études and validation of studies);

To avoid using two translation strategies for the same culture-bound term (e.g. specialista (specialist));

To create a glossary for the education-specific terminology (e.g. mention assez bien / upper second class honor minimum, or first class honor);

To render cultural presuppositions through explicitation, when needed (e.g. Asturias / the Principality of Asturias);

To opt for the culture-neutral terms over the local/national-specific references (e.g. tart instead of quiche, sandwich instead of panini, bachelor's degree instead of licence);

To refer to previous translations, esp. if retrievable from native English sources (e.g. flea market instead of braderie, Languages Café instead of Café Langues, students attending instead of frequentanti);

To maintain culture-bound terms if they carry important messages for the target audience (e.g. Family Allocations Office over deletion of CAF (Caisse d'Allocations Familiales)).

This case study has shown that the translation of culture may be a daunting task. The translator's effort to use the most appropriate strategies so as to convey the accurate message to the intended audience contributes to the 
success not only of the translation of university websites, but of the universities themselves, among international students.

\section{Works Cited}

Askehave, Inger and Anne Ellerup Nielsen. "Digital genres: a challenge to traditional genre theory”. Information Technology \& People, Vol. 18, Iss: 2, 2005, pp.120 - 141. Web. 10 Sep. 2016

Axielá, Javier Franco. "Culture-Specific Items in Translation”. Translation, Power, Subversion. Eds. Román Ȧlvarez and Carmen-Africa M. Vidal. Clevedon, UK: Multilingual Matters, 1996, pp. 52-78. Print

Chiaro, Delia. "Issues in Audiovisual Translation". The Routledge Companion to Translation Studies, Ed. Jeremy Munday, London: Routledge, 2009, pp. 141165. Print.

Dimitriu, Rodica. Theories and Practice of Translation. Iasi: Institutul European, 2002. Print.

---. $\quad$ "Omission in translation”. Perspectives. Studies in Translatology, Vol.12, Iss: 3, Clevedon, UK: Multilingual Matters, 2004, pp. 163-175. Print.

Hatim, Basil and Ian Mason. Discourse and the translator. London: Longman, 1990. Print.

Katan, David. "Translation as Intercultural Communication”. The Routledge Companion to Translation Studies. Ed. Jeremy Munday. London: Routledge, 2009, pp.7492. Print.

Leppihalme, Ritva. Culture Bumps: An Empirical Approach to the Translation of Allusions. Clevedon: Multilingual Matters, 1997. Print

Olk, Harald Martin. "The Translation of Cultural References: An Empirical Investigation into the Translation of Culture-Specific Lexis by Degree-Level Language Students”. PhD thesis, Canterbury: University of Kent, 2001. Web. 20 Jan. 2018.

Nelson, Kate. "Lille braderie: Biggest flea market in Europe cancelled amid security fears.” The Independent.co.uk., Aug. 2016. Web. 28 Sept. 2018.

Pedersen, Jan. "How is culture rendered in subtitles?" EU-High-Level Scientific Conference Series MuTra 2005 - Challenges of Multidimensional Translation: Conference Proceedings, 2005: 2. Web. 3Feb. 2018.

Ramière, Nathalie. "Reaching a Foreign Audience: Cultural Transfers in Audiovisual Translation". The Journal of Specialised Translation, Iss: 6, 2006, pp. 152-166. Print.

Schäffner, Christina. "Norms of translation." Handbook of Translation Studies. Vol. 1. Eds. Yves Gambier and Luc van Doorslaer. Amsterdam: John Benjamins, 2010, pp. 235-244. Print.

Snell-Hornby, Mary. Translation Studies. An Integrated Approach. Revised ed. Amsterdam: John Benjamins, 1988/1995. Print.

Trosborg, Anna. 1997. “Text Typology: Register, Genre and Text Type”. Text Typology and Translation. Ed. Anna Trosborg, Amsterdam: John Benjamins, 1997, pp. 323. Print. 